ARTICLE

https://doi.org/10.1057/s41599-020-0486-4 \\ OPEN
}

\section{Poe, insanity, and containing the feminine monstrous}

Tracy Hayes ${ }^{1 凶}$

\begin{abstract}
In fiction, unlike his life, Poe was able to contain his women. He derived many features from the European Gothic tradition, and utilized motifs such as incarceration, premature burial, and the pathetic fallacy, or the use of external landscape to express or reflect psychological turmoil. Poe's psychologically intense tales feature narrators whose mental fabric disintegrates before the reader's eyes. This essay will concentrate upon three such tales: 'Berenice' (1835), 'Ligeia' (1838), and 'The Fall of the House of Usher' (1839). Each of these stories are narratives of obsession and monomania featuring female incarceration and objectification, and the threat of the feminine monstrous. Berenice, Ligiea and Madeline Usher each embody the feminine monstrous in varying ways, a masculine projection of womanhood unrestrained, unsuccessfully repressed by their male counterparts, and thus returning in an act of unheimliche consummation. Berenice symbolizes the vagina dentata whose threat must be removed through dental extraction; Ligeia is an incubus who perverts the Eucharist in order to achieve an act of monstrous metempsychosis; and Madeline acts as both monstrare and monere: as both the warning and the source of impending destruction. The perceived female abandonment and thus betrayal which had become a pattern of Poe's life was through his fiction able to be halted and contained. The inextricable link between Eros and Thanatos undergirds these stories in which, in a mirror of Poe's own life, each love object wastes away during the prime of her beauty. This essay discusses the context of male-female relations in Poe's life and how they impact upon his fiction. Unlike reality, in his tales Poe was able to resurrect the objects of his obsessions, and thus the female figures comprising the monstrous loves of his male protagonists. However, this essay also questions the extent to which such resurrections and containment are successful within each narrative, and how far Poe's delineations of the feminine monstrous and unheimlich sexuality can be read as interrogations of compromised masculinity.
\end{abstract}

\footnotetext{
${ }^{1}$ Independent researcher, Middlesbrough, North Yorkshire, UK. ${ }^{{ }}$email: tracyhayes1840@gmail.com
} 


\section{Introduction: Poe and his women}

- he quotation in the title of this essay comes from a letter Poe wrote to his mother-in-law Maria Clemm not long before his death, referring to his mental derangement during the last stages of his wife Virginia's fatal illness (July 7 , 1849 , OL \#323). It can hardly be doubted that Poe was indeed a disturbed and tormented man, his many biographers have described him variously as a sadomasochist, an alcoholic and drug addict (he in fact never used drugs), a manic depressive, a sex pervert (Virginia was only 9 years old when he first met her, and 14 when they married), and an egomaniac (Galloway, 2003, p. xxxi). But while Poe's mental state may account for the tone and themes to which he repeatedly returned in his fiction, we must also take into consideration the life of the man who wrote that fiction. In doing so we note the common denominator of feminine abandonment and and thus betrayal, leading to a prominent feature of his stories-the conflation of beauty with death. Julian Symons notes that 'Beautiful women have little chance of survival in Poe. They are often seen both as the victims of men and as a cause of destruction' (Symons, 1978, p. 205). The characters of Berenice, Ligeia, Lady Rowena and Madeline Usher can be read as what Symons calls 'beautiful or horrific shadows existing only in the mind of the narrator' (Symons, 1978, p. 207). Each character is portrayed as representing a sexuality of perverseness, and each is indeed both a victim and, or, a cause of destruction.

Symons describes Poe's women as 'spectres, idealized images drained of blood' (Symons, 1978, p. 240), providing the necessary connection between Eros and Thanatos that undergirds Poe's oeuvre. Stephen Amos identifies Eros and Thanatos as the two major forces of all human impulse-the love and death drives of the Id. He describes Eros as a centripetal force which seeks unity and wholeness, and Thanatos as a centrifugal force seeking disunification and destruction-'Eros builds up, Thanatos tears down' (Asma, 2009, p. 215). Poe's women, both real and fictional, begin by seeking love and unity, but ultimately end in death and disunification. As Poe wrote in 'The Philosophy of Composition' (1846): 'the death, then, of a beautiful woman is, unquestionably, the most poetical topic in the world-and equally is it beyond doubt that the lips best suited for such topic are those of a bereaved lover' (Galloway, 2003, p. 436). Poe was a bereaved lover many times throughout his short life, each death compounding a morbid equation of beauty with mortality combined with a monstrous betrayal by the feminine in both nature and nurture in his personal aesthetic framework.

Karen Weekes notes that Poe "lost an unusual number of beautiful, relatively young, nurturing females in his lifetime' (Weekes, 2002, p. 149). Poe's mother had already contracted tuberculosis before his birth, and Peter Ackroyd conjectures that 'circumambient tension affects the unborn child. So the haunted life of Poe began before his birth' (Ackroyd, 2008, p. 8). Eliza Poe died when Edgar was two years old, she was only 24. At fourteen a schoolfriend, Robert Stanard, invited Poe to the Stanard's house where Robert's mother Jane, herself only 30 at the time, took Poe's hand 'and spoke some gentle and gracious words of welcome' (Ackroyd, 2008, p. 21). Poe became besotted with her, she died insane a year later. Poe's foster mother Frances Allan who loved him unconditionally, and to whom he was devoted, died when Poe was 20. In 1836 Poe married his cousin Virginia, whom he nicknamed Sissy, he was 27, she just 14. Almost all of these key biographical figures showed 'signs of consumption, a disease that kills its victims without destroying their appearance' (Weekes, 2002 , p. 149), a circumstance further undergirding the conflation of Eros with Thanatos-love and beauty with death-prevalent throughout Poe's work. Ackroyd posits that Poe 'possessed an unerring ability to choose frail, or in some way damaged, women', and that he regarded his relationships with women 'as ideal or spiritual in temper' (Ackroyd, 2008, p. 22). From this we may surmise that of all the things Poe feared, 'that of female withdrawal was by far the most painful' (Ackroyd, 2008, p. 134). And yet in a letter to his friend George Eveleth after Virginia's funeral, Poe declared with regards to his writer's block: 'I had indeed, nearly abandoned all hope of a permanent cure when I found one in the death of my wife' (January 4, 1848, OL\# 259). Being 'abandoned' by these women was undoubtedly devastating, but it also served as a release for Poe's psychic energies in the form of creative muse.

In fiction Poe was able to contain his women, to punish the recurring lack of feminine nurturing that early death brought to the betrayed male. This essay concentrates upon three such tales: 'Berenice' (1835), 'Ligeia' (1838), and 'The Fall of the House of Usher' (1839). Each of these stories are narratives of obsession featuring female incarceration and objectification, and the containment of the threat of the feminine monstrous. Berenice and Lady Rowena Trevanion are the wives of the narrator in their respective tales, and Lady Madeline is the twin sister to the narrator's friend; each of these women are reduced to the sum of their physical features rather than described in terms of personality. The exception to this is Ligeia, whose intellect and presence are delineated in infinite detail, and coincidentally she is the only woman of the four featured in the essay who is not a victim, but in fact the cause of the destruction of another. Teeth, hair, eyes and skin are fetishized to an extreme degree until each woman becomes a creature which must be contained. Once contained, there can be no abandonment or betrayal.

\section{The Unheimlich feminine monstrous}

Barbara Creed has written at length on the female monster, what she terms the 'monstrous-feminine', identifying various forms such as the witch, the bleeding wound, the possessed body (Creed, 1993, p. 1). She notes that the monstrous-feminine embodies 'what it is about woman that is shocking, terrifying, horrific, abject', and explores Freud's notion of the castrated/castrating mother in order to expose male anxieties surrounding female power (Creed, 1993). For Creed the phrase monstrous-feminine 'emphasizes the importance of gender in the construction of monstrosity' (Creed, 1993, p. 3). She sees the representation of woman as monstrous as being in most cases related to mothering and reproductive functions, and linked to questions of sexual desire (Creed, 1993, p. 7). As Poe's stories are remarkable for their lack of representing sexual desire, this essay posits that it is an unheimliche, or uncanny, monstrousness that is brought into play, chanelled through the feminine as as receptor of male repression. As Georges Canguilhem remarks, 'the monstrous is the marvellous inverted, but is is marvellous nonetheless. On the one hand, it disconcerts...on the other, it valorizes' (Canguilhem, 2008, p. 136). The instances of the feminine monstrous in Poe's stories are indeed marvellous, causing awe and wonder, and not a little trepidation, in the male protagonists seeking to contain what they cannot control. In the forms of Berenice, Ligiea and Madeline Usher the marvellous disconcerts both narrator and reader with its recourse to the uncanny, but it also valorizes an inchoate femininity whose partial or limited existence is ultimately uncontainable. A point to mention here is that Poe's story 'The Black Cat' (1843) has not been included in this essay for a number of reasons, even though it concludes with the narrator's wife being bricked up behind a cellar wall. At no point in the story is the wife portrayed as monstrous, or a threat to her husband. She is not the receptor of male repression, but the victim of physical abuse caused through her husband's 
alcoholism. The narrator both contains and controls his wife, it is the cat Pluto who acts as a catalyst for his unravelling psychological instability, and Pluto is presented as a male.

Two of Creed's categories in particular are of relevance to this essay: the 'woman as life-in-death', and 'woman as the deadly femme castratrice' (Creed, 1993, p. 1). Ligeia and Madeline Usher are each symbols of the feminine monstrous as life-in-death, and Berenice is the unwitting castratrice, whose teeth are removed by the narrator in order to 'gain mastery over the ideas they represent' (Weekes, 2002, p. 156). The male protagonists of these three stories each suffer from a hypersensitivity, an almost aesthetic insanity, rendering defective the senses of sight, sound and taste. Their unstable psyches are translated as perverted quests for a monstrous form of love, the monstrousness being transferred onto the female object of devotion who seemingly perishes from a wasting disease only to return in an embodiment of Sigmund Freud's unheimliche, the 'unhomely' monstrous which should remain suppressed, but reappears, evoking fear and dread. As David Punter and Glennis Byron note:

In Poe, things constantly return; but whether they return from an outer world or because they have never been banished from unconscious depths of the psyche remains a problem which is irresolvable, and the very brevity of the tales serves to reinforce the fundamental impossibility of answering such a question (Punter and Byron, 2004, p. 156).

Freud was 'the pioneer in the science of monstrous feelings' (Asma, 2009, p. 189). He posits that the unheimliche, or the uncanny, is caused by the return of the repressed, something that was long familiar to the psyche but has become estranged (Freud, [1919] 2003, p. 147, 148). Berenice, Ligiea and Madeline each embody the feminine monstrous, a masculine projection of womanhood unrestrained by the duty to nurture the male, unsuccessfully repressed by their male counterparts and thus returning in a perverted act of monstrous consummation.

\section{Berenice and monomania}

'Berenice' is a morbid and macabre tale, one of Poe's earliest, it set the tone for what was to follow. It was published in the supposedly genteel pages of The Southern Literary Messenger in 1835, in the words of Kenneth Silverman, 'with the effect of an affront, its air of madness and desecration violating the magazine's standard of propriety' (Silverman, 1991, p. 110). The publisher, Thomas Willis White, had criticized it as being far 'too horrible', to which Poe replied that the most successful stories contained 'the ludicrous heightened into the grotesque: the fearful coloured into the horrible: the witty exaggerated into the burlesque: the singular wrought out into the strange and mystical. You say all this is bad taste. I have my doubts about it' (April 30, 1835, OL\# 042). What Poe referred to as the grotesque and the arabesque, or licentiousness and transcendence, is a recurring theme throughout his tales. The 'ludicrous' nature of the protagonist's obsession with teeth in 'Berenice' is heightened into the grotesque by the method he chooses to appease his monomania.

'Berenice' is one of the first pieces of fiction to mention the condition of monomania by name, a psychosis characterized by obsessive thoughts confined to a singular idea. Not officially recognized until 1845 with the publication of the French physician Jean-Etienne Esquirol's Mental Maladies, a Treatise on Insanity, it was viewed as a partial insanity conceived as a single pathological preoccupation. Thus far only two examples predate Poe's usage-Balzac's Eugénie Grandet (1833), and a painting of 1822 by Théodore Gericault titled 'Insane Woman', or 'Monomania of Envy'. Poe anticipated Esquirol's theories by a decade, featuring the condition in both 'Berenice' and 'Ligeia', and also in 'The Tell-Tale Heart' (1843). The protagonist of 'Berenice', the psychologically morbid Egaeus, early in the narrative describes himself as diseased: 'my own disease grew rapidly upon me, and assumed finally a monomaniac character of a novel and extraordinary form-hourly and momently gaining vigour-and at length obtaining over me the most incomprehensible ascendancy' (Poe, [1835] 2012, p. 228). The focus of Egaeus's ideé fixeé is teeth, specifically those of his young cousin Berenice, to whom he became betrothed in a moment of spite when he noticed that she was suffering from a mysterious wasting disease which thus ensured the negation of procreation and nurturing. Egaeus has never felt any kind of love or warmth for his cousin, but once her emaciation becomes excessive, and he contemplates her 'thin and shrunken lips' which part in a 'smile of peculiar meaning', 'the teeth of the changed Berenice disclosed themselves slowly to my view. Would to God that I had never beheld them, or that, having done so, I had died!' (Poe, [1835] 2012, p. 231). One of Poe's many aesthete protagonists who has spent most of his life sequestered in a study where 'the realities of the world affected me as visions only', and where 'the wild ideas of the land of dreams' became his sole existence (Poe, [1835] 2012, p. 228), Egaeus awakens to a new disorder of the brain, an obsession with 'the white and ghastly spectrum of the teeth' (Poe, [1835] 2012, p. 231). Creed writes of 'teeth dreams' representing fears of castration (Creed, 1993, p. 117), but in this particular text teeth are instead the focus of Egaeus's monomania. The reader is captivated and forced to share in the fracturing of Egaeus's psyche: 'The teeth! - the teeth! - they were here, and there, and everywhere, and visibly and palpably before me; long, narrow, and excessively white, with the pale lips writhing about them' (Poe, [1835] 2012, p 231). Poe's use of the word 'writhing' is particularly telling in this instance, connoting as it does the movement of a snake, the creature symbolic of the most powerful image of the feminine monstrous in mythology-the Medusa. Where Creed describes the Medusa as femme castratrice controlling the sadistic gaze, and the male victim being her object (Creed, 1993, p. 153), in 'Berenice' this trope is inverted. Berenice is never other than passive, the sadistic gaze is controlled by her cousin Egaeus.

For hours after Berenice has left his study Egaeus remains fixated upon 'the phantasma of the teeth...most vivid and hideous' (Poe, [1835] 2012, p. 232). Eventually he is roused from his mental torpor by the news that Berenice has succumbed to a fatal epileptic siezure, and is to be buried at the close of the following day. There follows an abrupt break in the narrative commensurate with the psychotic break of the protagonist. Suddenly Egaeus awakes, once again in his study, in a state of confusion, unable to recall the last few hours, only that he 'had done a deed' with the 'piercing shriek of a female voice' ringing in his ears (Poe, [1835] 2012, p. 232). He discovers a little box next to him, and a book of poetry by Ebn Zaiat open with a particular phrase underlined: 'Dice bant mihi sodales si sepulchrum amicae visitarem curas meas aliquantulum fore levatas', or: 'My companions told me I might find some little alleviation of my misery in visiting the grave of my beloved' (Poe, [1835] 2012, p. 233). Berenice has been mistakenly buried alive by the household who are ignorant of the symptoms of extreme epileptic catatonia, and it is while Egaeus is somnambulistically extracting each of her 32 teeth, 'small, white and ivory-looking substances' that she regains consciousness (Poe [1835] 2012, p. 233). Poe makes no attempt to explain the nature of a person who could perform such a hideous act, nor does he attempt to pass any kind of judgement, he simply suggests that, in the words of Julian Symons, 'madness is an aspect of a higher awareness outside literal reality' (Symons, 1978, p. 213). Madness, driven by monomania, creates in Egaeus an awareness of what has subconciously been repressed-the need for the removal of 
the vagina dentata, the threat of the feminine monstrous as castratrice, of emasculation. Weekes reads this act as the desexualization of the corpse, a removal of the 'token of devouring carnality' (Weekes, 2002, p. 156). Berenice is ultimately reduced to that which can be contained, a small box of teeth and dental instruments. Her monstrous beauty and unheimlich sexuality are grotesquely disfigured in an act of perverted castration, culminating in the destruction of both Egaeus's muse and his mental equilibrium.

\section{Ligeia and feminine violation}

Rather than a linear narrative 'Ligeia' is a foray into metempsychosis, a study of transcendence, and once again features monomania. It concerns the nature of existence after death, for Poe's fiction shows an interest in the possibility that an individual personality might continue after death, either through an effort of will or by some extraneous means. The survival after death in some form of physical continuance is the animating principle of 'Ligeia'. Each of the women in this tale is reduced to the sum of her physical features, the feminine fragmented into constituent parts, objectified and fetishized. Ligeia's 'exquisite beauty' is dwelt upon at length to the point of idolatry; eyes, mouth, hair and skin are fetishized to an intensely psychological degree in passages that continue for many pages. In contrast the Lady Rowena Trevanion is diminished to a few words: 'fair-haired and blue-eyed', in the ultimate act of containment she is denied even the privilege of speech.

In 'Ligeia' the focus of obsession is the eyes, they become a synechdoche for the lady herself. Ackroyd relates how Poe claimed that 'the tale was inspired by a dream in which he saw nothing but female eyes' (Ackroyd, 2008, p. 68), and it is perhaps significant that one of the only known images of Poe's mother Eliza, an illustration housed in the Valentine Museum in Richmond,Virginia, features a young lady whose eyes are so large that their prominence dwarfs the rest of her features (reproduced in Ackroyd, 2008). The narrator's description of his wife's eyes continues for more than one and a half pages: 'the large eyes of Ligeia' for which 'we have no models in the remotely antique... something more profound than the well of Democritus-which lay far within the pupils of my beloved' (Poe, [1838] 2012, p. 258). Poe's narrator goes to great lengths to describe the marriage to Ligeia as a communion of souls, endowing her with the ethereality of a deity: 'her presence...rendered vividly luminous the many mysteries of transcendentalism in which we were immersed'(Poe, [1838] 2012, p. 259). Her 'immense' learning is so utterly 'gigantic' that the narrator is 'sufficiently aware of her infinite supremacy to resign myself, with a childlike confidence, to her guidance through the chaotic world of metaphysical examination' (Poe, [1838] 2012, p. 259). Poe delineates a relationship so obsessive that it transcends time, and ultimately death itself. Ligeia inevitably wastes away in the prime of her youth and beauty, and the motifs of repression and imprisonment are represented both in the narrator's insistence on existing within the realm of memory rather than physicality, 'Ligeia, the beloved, the august, the beautiful, the entombed' (Poe, [1835] 2012, p. 264), and in containing the second wife Rowena's role within the narrative entirely to one room, a bridal chamber ornamented with the paraphernalia of death. Here Eros and Thanatos are linked irrevocably in Rowena's confinement to a matrimonial funeral parlour. The chamber has been specifically decorated by the narrator in black and gold, containing ebony furniture with 'pall-like' canopies, and giant sarcophagi of black granite standing on end in each corner. Ligiea's betrayal of the narrator by abandoning their spiritual union via an early death is translated into an abhorrence by him of his second wife. The narrator loathes Rowena 'with a hatred belonging more to a demon than to a man' (Poe, [1838] 2012, p. 264), recalling Egaeus's feelings of contempt for his cousin Berenice. Consequently Rowena shuns her husband, and wastes away in her turn, suffering fever and violent convulsions that 'attack her frame, at all times feeble' and emaciated (Poe, [1838] 2012, p. 264).

Creed notes that it is 'the border' which is 'central to the construction of the monstrous', the border between human and non-human, corporeality and incorporeality (Creed, 1993, p. 11). In line with the feminist theories of Julia Kristeva Creed proposes that 'that which crosses or threatens to cross the border is abject', for it is at the border that the monstrous is produced (Creed, 1993). The haunting of Rowena Trevanion heralds the proximity of the border, and the coming of the feminine monstrous that is Ligiea. Rowena hears things and sees things that the narrator in his opium fugue does not at first observe, until at last he becomes aware of 'a faint, indefinite shadow of angelic aspect' which introduces 'three or four large drops of a brilliant and ruby coloured liquid' into Rowena's medicinal goblet (Poe, [1838] 2012, p. 265). The blood of Ligeia as Christ acts as a macabre transference of the Eucharist, causing not life, but a metempsychosis. Rowena dies, is enshrouded for the tomb, and the narrator sits with her body in the bridal chamber of death, where he 'again gave myself up to passionate waking visions of Ligeia' (Poe, [1838] 2012, p. 265). A night of terror ensues in which the border between corporeality and incorporeality is continually breached, a repeated 'hideous drama of revivification', until the metempsychosis is complete (Poe, [1838] 2012, p. 267). Daniel Hoffman asks 'Are these the throes of the dying body struggling to live, or the living body struggling to die?... a repeated excited violation of the body in successive, spasmodic orgasm' (Hoffman, 1985, p. 256). This violation is perpetrated upon one female by another, a violent transcendence that begins with invasion and ends in transmogrification. Ligeia's last words in life had been 'Man doth not yield him to the angels, nor unto death utterly, save only through the weakness of his feeble will' (Poe, [1838] 2012, p. 262). Does Ligeia reappear in Rowena's body because she wills to return to her husband, or because her husband wishes her return? In this instance, containing the feminine has in fact released the monstrous. In an unheimliche act that which had been repressed has now returned. Ligeia returning to the bridal death chamber is a powerful example of Poe's Ideal replacing the real, the Grotesque impinging upon the Arabesque. The unheimlich act of metempsychosis ushers in the return of the monstrous sexuality of Ligiea, monstrous in its devouring consummation of another female. After the narrator has physically contained Rowena, she is then corporeally contained by Ligeia as the conduit through which she may return. The ambiguous nature of this story is such that the reader is left wondering exactly what had been repressed, and to what end, before re-emerging in a state calculated to cause shock, awe and dread? As Ackroyd observes of this particular story: 'The dead are never wholly dead, and Poe comforts himself with. these dreams of the revenant' (Ackroyd, 2008, p. 69).

\section{Madeline usher and the failure to contain}

Punter and Byron posit that 'Etymologically speaking the "monster" is something that serves to demonstrate (from the Latin monstrare) and to warn (in Latin monere). From Classical times monsters were interpreted either as signs of divine anger or as portents of impending disasters' (Punter and Byron, 2004, p. 263). Stephen Asma notes that to be a monster is to be an omena portent of the future, 'a display of God's wrath', a symbol of moral vice, or an accident of natue (Asma, 2009, p. 13). The epitome of the feminine monstrous, Madeline Usher serves to act as both monstrare and monere-she is a portent of the moral and 
literal fall of the Usher line and it's house. 'The Fall of the House of Usher' is one of Poe's most powerful and enduring works. David Blair describes the story as exploiting 'the very Gothic idea of the degenerate legacy of a decaying European aristocracy' (Blair, 2002, p. xv). Hoffman quips that the story is a veritable 'thesaurus of Gothic clichés'-lonely wanderer, dreary landscape, decaying castle, demented genius, sickly spectral sister, and he even reads into the tale an incestuous attachment between Roderick and Madeline (Hoffman, 1985, pp. 296-297). In a somewhat Freudian interpretation of Roderick Usher's intentions he notes that 'To love one's twin sister is but a double displacement for the ultimate narcissism, self-love, and the ultimate incestuous desire, possession of one's mother's body' (Hoffman, 1985 , p. 311). This reductive reading of Poe's story can be countered with the idea that it is not the (absent) mother's body that Roderick wishes to possess, but rather the larger notion of containing the feminine in order to control its monstrous threat to a particular patriarchal milieu. Roderick needs to contain his sister in order to perpetuate the Usher line: "Her decease," he said, with a bitterness which I can never forget, "would leave him (him the hopeless and the frail) the last of the ancient race of the Ushers"“ (Poe, [1839] 2012, p. 303). However it is Roderick Usher's psychological instability and encroaching psychotic breakdown that are ultimately what terminates the lineage.

Roderick suffers from a malady described as 'a constitutional and a family evil, and one for which he despaired to find a remedy' (Poe, [1839] 2012, p. 303). One could be forgiven for assuming that the malady in question is syphilis, a scourge of families throughout the nineteenth century and a trope favoured by later writers such as Max Nordau, Sarah Grand and Henrik Ibsen. But Roderick is in fact portrayed as being afflicted with neurasthenia to the point of psychological instability, a form of moral insanity passed down through the generations of his family. The Usher line dates back many centuries, and the family estate is a secluded 'mansion of gloom' by a dank lake in the mountains (Poe, [1839] 2012, p. 299). Roderick and his twin sister Madeline are the last of their line. Lacking collateral issue, they are recluses ensconced in a bygone world which is now fallen into a state of desuetude. Roderick knows that he will not survive much longer: 'I shall perish...I must perish' (Poe, [1839] 2012, p. 303), and he invites an unnamed schoolfriend, the narrator, for a prolonged visit in order to alleviate 'the mental disorder which oppressed him' (Poe, [1839] 2012, p. 300). Roderick is portrayed as cultured, over-sensitive, and a scholar of the esoteric. Some critics conjecture that he is partly a portrait of Poe himself-a melancholic aesthete whose eccentricities alienated him from the rest of his society (Galloway, 2003, p. li). Usher is what we might now term a manic depressive, or one suffering from bipolar tendencies, with a strong element of hysteria in his depression (Symons, 1978, p. 237). His moods swing unpredictably between desolation and ecstacy without warning, leaving both the narrator and the reader in a state of anxiety as to how Roderick's debilitated mental fabric will dictate the plot of the tale.

Usher is cadaverous in appearance, and the passage which describes his suffering from 'a morbid acuteness of the senses' again recalls the character of Egaeus: 'the most insipid food was alone endurable; he could wear only garments of a certain texture; the odours of all flowers were oppressive; his eyes were tortured by even a faint light; and there were but peculiar sounds, and these from stringed instruments, which did not inspire him with horror' (Poe, [1839] 2012, p. 303). However, this delineation of Usher is much more rarified than that of Egaeus, indicating that in the 4 years separating the two tales Poe had refined the aesthetic component of his character development. This almost vampiric imagery is extended to Madeline, a narcoleptic and yet another beautiful young woman suffering from a wasting disease. Yet her presence, although she is only glimpsed (alive) on two occasions by the narrator, permeates the house. Her mysterious hold over her brother is such that after her initial 'death' Roderick insists on preserving her body in one of the many vaults beneath the mansion for 2 weeks prior to her official interment. As Roderick and the narrator convey her body to the designated place of repose there is noticed 'a faint blush upon the bosom and the face, and that suspiciously lingering smile upon the lip which is so terrible in death' (Poe, [1839] 2012, p. 309). Madeline dwells at the border, her unheimlich monstrousness rendered abject. This scene seems to anticipate Bram Stoker's Lucy Westenra, another beautiful young woman punished for a monstrous sexuality, who after 'dying' subsequent to being seduced by Count Dracula, lies in repose with skin the colour of marble, except for a faint blush upon her cheeks and a rictus smile, only to 'return' in order to prey upon children in the guise of the Bloofah Lady. Indeed as Roderick and Madeline are twins the reader could be forgiven for wondering if they have in fact been feeding from each other, the advancement of their consumption having occurred in mirror-like parallel.

Madeline's body is placed in a copper coffin, which in turn is deposited into a vault with an iron door, used by previous generations of Ushers as a torture chamber. According to the 'Seven Noble Elements of the Ancients' recorded by the eighteenthcentury Benedictine librarian Dom Antione-Joseph Pernety in Dictionnaire Mytho-Hermetique (1758), copper was associated with eternal feminine youth, and iron was regularly used as a ward against ghosts and spirits. This coupled with Roderick's preferred reading material which includes Tommaso Campanella's City of the Sun (1602), a theocratic work based upon the principles of physiognomy and the immortality of the soul; Emanuel Swedenborg's Heaven and Hell (1758) describing the afterlife and how one may continue to exist after corporeal death; and Nicholas Eymerich's Directorium Inquisitorum (1376), a treatise on sorcery, signifies that Roderick took steps to ensure that Madeline, and all she represents, was properly contained. However the threat of the feminine monstrous remains. Subsequent to Madeline's premature transferral to the vault the narrator has nightmares of an incubus sitting on his chest; indeed Fuseli's 'The Nightmare', originally painted in 1782, is directly alluded to earlier in the text (Poe, [1839] 2012, p. 305). Roderick, already extremely psychologically unstable, descends into madness, claiming to hear signs of his sister's impending return, the return of what he has attempted to repress and contain. During a tempest, a favoured Gothic trope, the narrator reads aloud the tale of The Mad Trist of Sir Launcelot Canning in a misguided attempt to distract Usher from his deepening psychosis. This metafiction is a creation of Poe's during which sounds and effects occurring in the central story become transmuted into those of Madeline's escape from coffin and vault in the framing narrative, enhancing the unheimliche nature of the events portended. Symons observes that 'Madeline was a part of himself which Roderick felt bound to destroy' (Symons, 1978, p. 237), and she in turn seeks her brother, returning from the border from whence her abjection is magnified in the feminine monstrous: 'For a moment she remained trembling and reeling to and fro upon the threshold, then, with a low moaning cry, fell heavily inward upon the person of her brother, and in her violent and now final death agonies, bore him to the floor a corpse, and a victim to the terrors he had anticipated' (Poe, [1839] 2012, p. 313). Madeline Usher is the feminine monstrous that could not be contained, serving both to demonstrate a divine anger (monstrare) at the presumption of one who seeks knowledge beyong the border of the corporeal, and to warn of impending disaster (monere). With her unheimliche return the House of Usher is rent asunder and engulfed by the pestilential waters of the surrounding tarn. Unable to sustain itself any longer, the noble line of Usher becomes extinct. 


\section{Conclusion}

In each of these three tales, as in much of Poe's fiction, women have been 'othered' by men who retain only a tenuous grip on reality; men who are compromised by emasculation, and thus must contain the feminine monstrous lest it threaten the patriarchal milieu. Objectified and fetishized to an extreme degree Berenice, Ligeia, Rowena and Madeline are examples of Julia Kristeva's notion of the abject, symbolizing the unheimliche and the subsequent necessity for repression. Weekes observes that each of the male protagonists seems 'curiously removed from physical passion or any vestige of empathy... when they are overcome with emotion, they become corpse-like' (Weekes, 2002, p. 151). She cites the blood congealing in the veins of Egaeus while reading the words of Ebn Zaiat in 'Berenice', the interrupted heart beat and rigid limbs of the narrator in 'Ligeia' upon the revivification of Rowena, and the sight of Madeline Usher sending 'that story's narrator into a stupor' (Weekes, 2002, p. 151). This chimes with the notion that unlike Creed who sees the 'monstrous-feminine' as linked with reproductive functions and sexual desire, these are instead instances of an unheimliche monstrousness channeled through the feminine, highlighting male repression and psychological instability, and thus the need for containment. Berenice is reduced to a monstrous vagina dentata whose containment is guaranteed by the removal of her teeth, 'small,white and ivory substances' that are deposited into a small box on Egaeus's desk. The Lady Rowena becomes a conduit for the unheimliche return of the deified Ligeia, an entity who perverts the Eucharist in an act of female on female violation with the aim of transcending the physical barriers to a spiritual metempsychosis. And Madeline Usher, both monstrare and monere, who must be contained by her brother using principles outlined within the 'Seven Noble Elements of the Ancients' in an attempt to avert a 'decease' which 'would leave [Roderick] (him the hopeless and the frail) the last of the ancient race of the Ushers'. The perceived feminine abandonment and thus betrayal which had become a pattern of Poe's life was one which he aimed to subvert through the vehicle of fiction. The link between Eros and Thanatos undergirds these stories in which, in a mirror of Poe's own life, each woman wastes away during the prime of her beauty, thus denied and denying the possibility of nurturing the male. In fiction Poe was able to resurrect, and to an extent contain the monstrous loves of his male protagonists. The death of a beautiful woman is the most poetical topic in the world, but only if one is able to contain the feminine monstrous which lies beneath such beauty.

Received: 9 December 2019; Accepted: 5 May 2020;

Published online: 26 May 2020

\section{References}

Ackroyd P (2008) Poe: a life cut short. Chatto \& Windus, London

Asma S (2009) On monsters: an unnatural history of our worst fears. Oxford University Press, Oxford

Blair D (2002) Gothic short stories. Wordsworth Editions, Hertfordshire

Canguilhem G (2008) Knowledge of life. Fordham University Press, Victoria

Creed B (1993) The monstrous-feminine: film, faminism, psychoanalysis. Routledge, London

Freud S (2003) The uncanny (trans: McLintock D (1919)). Penguin Modern Classics, London

Galloway D (2003) Edgar Allan Poe: the fall of the house of usher and other writings. Penguin Classics, London

Hoffman D (1985) Poe, Poe, Poe, Poe, Poe, Poe, Poe. Vintage Books, New York

Poe EA (2012) Edgar Allan Poe: complete tales and poems. Fall River Press, New York

Punter D, Byron G (2004) The gothic. Blackwell Publishing, Oxford

Silverman K (1991) Edgar A. Poe: mournful and never-ending performance. Harper Collins, New York

Symons J (1978) The tell-tale heart: the life and works of Edgar Allan Poe. Penguin Books, Middlesex

Weekes K (2002) Poe's feminine ideal. In: Hayes Kevin J (ed.) The Cambridge companion to Edgar Allan Poe. Cambridge University Press, Cambridge, pp $148-162$

\section{Competing interests}

The author declares no competing interests.

\section{Additional information}

Correspondence and requests for materials should be addressed to T.H.

Reprints and permission information is available at http://www.nature.com/reprints

Publisher's note Springer Nature remains neutral with regard to jurisdictional claims in published maps and institutional affiliations.

\begin{abstract}
Open Access This article is licensed under a Creative Commons Attribution 4.0 International License, which permits use, sharing, adaptation, distribution and reproduction in any medium or format, as long as you give appropriate credit to the original author(s) and the source, provide a link to the Creative Commons license, and indicate if changes were made. The images or other third party material in this article are included in the article's Creative Commons license, unless indicated otherwise in a credit line to the material. If material is not included in the article's Creative Commons license and your intended use is not permitted by statutory regulation or exceeds the permitted use, you will need to obtain permission directly from the copyright holder. To view a copy of this license, visit http://creativecommons.org/ licenses/by/4.0/.
\end{abstract}

(C) The Author(s) 2020 